\title{
Bacteriophage MS2 As a Tool for Targeted Delivery in Solid Tumor Chemotherapy
}

\author{
E. F. Kolesanova ${ }^{1 *}$, M. V. Melnikova', T. N. Bolshakova ${ }^{2}$, E. Yu. Rybalkina ${ }^{3}$, I. G. Sivov ${ }^{4}$ \\ ${ }^{1}$ Institute of Biomedical Chemistry, Pogodinskaya Str. 10, bld. 8, Moscow, 119121, Russia \\ ${ }^{2}$ N.F. Gamaleya Federal Research Center of Epidemiology and Microbiology, Gamalei Str. 18, \\ Moscow, 123098, Russia \\ ${ }^{3}$ Institute of Carcinogenesis, Federal National Medical Research Center of Oncology, Kashirskoe sh. \\ 23, Moscow, 115478, Russia \\ ${ }^{4}$ Biotechnologiya, Ltd., Efremova Str. 20, Moscow, 119048, Russia \\ *E-mail: ekaterina.kolesanova@ibmc.msk.ru \\ Received January 29, 2019; in final form, March 28, 2019 \\ DOI: $10.32607 / 20758251-2019-11-2-98-101$ \\ Copyright ( $) 2019$ National Research University Higher School of Economics. This is an open access article distributed under the Creative Commons \\ Attribution License, which permits unrestricted use, distribution, and reproduction in any medium, provided the original work is properly cited.
}

ABSTRACT Bacteriophage MS2 was employed for targeted delivery of an apoptosis-inducing agent, $\mathrm{Tl}^{+}$, into a tumor tissue. The targeted delivery was ensured by iRGD peptide, a ligand of integrins presumably located on the surface of endotheliocytes of the tumor tissue neovasculature and certain tumor cells. The synthesized peptide was conjugated to $\mathrm{MS} 2$ capsid proteins. $\mathrm{Tl}^{+}$ions from $\mathrm{TINO}_{3}$ penetrated the phage particles and tightly bound to phage RNA. Peptide-modified MS2 preparations filled with $\mathrm{Tl}^{+}$caused cell death in two types of cultivated human breast cancer cells and effected necrosis of these tumor xenografts in mice. Neither peptide-conjugated bacteriophage MS2 without $\mathrm{Tl}^{+}$nor the phage filled with $\mathrm{Tl}^{+}$but without the peptide or the same phage with the non-conjugated peptide in solution produced such effects. The preparation exhibited no acute toxicity at a therapeutic dose.

KEYWORDS bacteriophage MS2, iRGD peptide, thallium (I) ions, targeted therapy, breast cancer.

ABBREVIATIONS BC - breast cancer; DMAI - dimethyl adipimidate; $\mathbf{E D}_{50}$ - effective dose (the dose that causes an effect equal to $50 \%$ of the maximal one); HPLC - high-performance liquid chromatography; $L_{50}-$ dose of a $^{2}$ substance lethal to $50 \%$ tested animals; PFU - plaque-forming units; SDS - sodium dodecyl sulfate.

\section{INTRODUCTION}

Recently, efforts by researchers involved in the development of anti-tumor drugs have focused on targeted therapeutic agents based both on novel and already-known cytostatic drugs [1]. The use of nanocontainers (liposomes, micelles, polymer nanoparticles, virus-like particles, and viruses) modified with specific ligands filled with a drug is considered the most efficient delivery method [2]. However, these innovative delivery methods do not solve the problem of cancer multidrug resistance, which has the potential to undermine all previous efforts to enhance drug efficacy [3].

It has been demonstrated that $\mathrm{Tl}^{+}$ions exhibit strong cytotoxic activity and inhibit the cancer drug resistance-associated protein that acts as an efflux pump [4]. Incorporation of $\mathrm{Tl}^{+}$into a "non-leaking" nanosized container equipped with a targeted delivery system could allow one to develop an efficient tool for tumor destruction, while the overall toxicity of $\mathrm{Tl}^{+}$can be significantly mitigated. In the $1980 \mathrm{~s}, \mathrm{Tl}^{+}$ions were successfully entrapped in cowpox virus particles [5]. The entrapment mechanism involved the formation of a strong conjugate between $\mathrm{Tl}^{+}$and viral RNA [6]. The bacteriophage MS2 selected as a nanocontainer can reproduce itself only in Escherichia coli cells that carry F-pili and are neither human symbionts nor pathogens [7]. The delivery direction was ensured via conjugation of phage capsid proteins and the (Gly) $)_{3}$-iRGD peptide carrying the cycloSS-(CRGDKGPDC) (iRGD) moiety, which is responsible for binding to integrins that predominantly localize on the outer membranes of endothelial cells of the pathological neovasculature of solid tumors and on a number of tumor cells [8]. In this study, we experimentally tested the effectiveness of $\mathrm{Tl}^{+}$-filled bacteriophage MS2 carrying a targeting peptide as a candidate antitumor agent.

\section{EXPERIMENTAL}

The procedure used to prepare bacteriophage MS2 was described earlier in [9]. The number of plaque-forming units (PFUs) per milliliter of the phage preparation was identified by agar overlay assay. 
(Gly)3-iRGD peptide was prepared by automated solid-phase synthesis using 9-fluorenylmethoxycarbonyl amino acids (ChemPep, USA) on a 433A peptide synthesizer (Applied Biosystems) through the FastMoc method. The $\mathrm{S}-\mathrm{S}$ bridge was formed by oxidation with $\mathrm{I}_{2}$ [10]. The peptide was purified by reversed-phase HPLC (YMC-Triart C18 column, $21 \times 250 \mathrm{~mm}, 10.0 \mu \mathrm{m}$, Switzerland; Agilent 1100 working station, Agilent, USA), elution by $\mathrm{CH}_{3} \mathrm{CN}$ (BioSolve, Israel) concentration gradient in water containing $0.1 \%$ acetic acid. According to the data obtained by analytical reversedphase HPLC (YMC-Triart C18 column, $2.1 \times 50 \mathrm{~mm}$, $2.0 \mu \mathrm{m}$, Agilent 1200 working station) with UV and mass-spectrometry detection, purity of the peptide preparation was $\geq 95 \%$.

(Gly) ${ }_{3}$-iRGD peptide was conjugated to bacteriophage MS2 capsid proteins using a homobifunctional reagent dimethyl adipimidate (DMAI, Sigma, USA) at a phage protein : peptide : DMAI molar ratio of $1: 20$ : 80 , using the procedure described in [11]. The bacteriophage was separated from the excess reagents via precipitation with a $25 \%$ polyethylene glycol 6000 solution (Dia-M, Russia) containing $1 \mathrm{M} \mathrm{NaCl}$. The precipitated bacteriophage was suspended in deionized water.

The bacteriophage was filled with $\mathrm{Tl}^{+}$using $\mathrm{TlNO}_{3}$ (Sigma-Aldrich, USA). The peptide-conjugated bacteriophage MS2 (iRGD-MS2) (10 $\left.{ }^{11} \mathrm{PFUs}\right)$ was incubated in $3 \mathrm{ml}$ of a $0.5 \mu \mathrm{M} \mathrm{TlNO}{ }_{3}$ solution $\left(5 \mathrm{~h}\right.$ at $38^{\circ} \mathrm{C}$ ), followed by precipitation according to the procedure described above and dialysis against phosphate buffered saline (0.14 M NaCl, $0.01 \mathrm{M}$ sodium phosphate, $\mathrm{pH} 7.4$ ).

The amounts of $\mathrm{Tl}^{+}$ions both inside and outside the virions (in the medium) were determined using the procedure described in [12]. A suspension of bacteriophage particles filled with $\mathrm{Tl}^{+}$was centrifuged for $10 \mathrm{~min}$ at 5,000 rpm to remove the thallium salt precipitate, diluted with $50 \mathrm{mM}$ Tris-HCl buffer ( $\mathrm{pH} 9.0$ ) until a nominal concentration of $10^{8} \mathrm{PFUs} / \mathrm{ml}$, and denatured by heating with RNase in $0.05 \% \mathrm{SDS}$ at $+70^{\circ} \mathrm{C}$ for $30 \mathrm{~min}$. Quenching of 1,3,6,8-pyrene tetrasulfonic acid fluorescence by $\mathrm{Tl}^{+}$ions was then recorded (excitation wavelength, $340 \mathrm{~nm}$; emission wavelength, 465 $\mathrm{nm}$ ) on an UV-1900 spectrofluorometer (BOC Sciences APP, USA). A calibration curve showing the dependence between the fluorescence quenching degree and $\left[\mathrm{Tl}^{+}\right]$was used to calculate the content of $\mathrm{Tl}$ in the bacteriophage preparation. The $\mathrm{Tl}$ content in the buffer solution after dialysis was determined without pre-denaturation.

The cytotoxic effect of iRGD-MS2- $\mathrm{Tl}^{+}$on the cell cultures was studied using MCF-7 (hormone-dependent breast cancer) and MDA-MB-231 (hormoneindependent breast cancer) cell lines. The cells were cultured in a serum-free medium (MSC1 Pan Bio-
Tech) and in the same medium supplemented with $5 \%$ fetal calf serum. The iRGD-MS2- $\mathrm{Tl}^{+}$preparation was added in 10-fold dilutions, starting with a concentration of $10^{8} \mathrm{PFU} / \mathrm{ml}$. The iRGD-MS2 preparation (the peptide-conjugated bacteriophage without $\mathrm{Tl}^{+}$) was used as a control. Dead cells were counted after staining with Evans blue. The antitumor effect of the iRGD-MS2- $\mathrm{Tl}^{+}$preparation was tested in nude mice with MCF-7 or MDA-MB-231 cancer cell-derived xenografts. The mice were injected with $10^{5}-10^{6} \mathrm{MCF}-7$ or MDA-MB-231 cells intradermally. Fourteen days later, the mice in the experimental groups received $200 \mu \mathrm{l}$ of a suspension containing iRGD-MS2- $\mathrm{Tl}^{+}$at a dose corresponding to $10^{8} \mathrm{PFU} / \mathrm{kg}$ intraperitoneally during 10 days (once per day). Mice in the control group were injected with iRGD-MS2, MS2- $\mathrm{Tl}^{+}$, or $\mathrm{MS}-\mathrm{Tl}^{+}+\mathrm{iRGD}(2 \mu \mathrm{g} / \mathrm{kg}$ in solution) of the MS2 dosage equal to the iRGD-MS2- $\mathrm{Tl}^{+}$doses for experimental animals, and in the same volume of the solution. Each experimental and control group consisted of 11 animals. The necrotic activity of the preparation was determined as a ratio between the area of necrosis tissue and the total area of the tumor by analyzing digital images of histologic sections recorded using a ScanScope CS2 scanner 12 days after the last injection of bacteriophage preparations.

Acute toxicity of the iRGD-MS2-Tl ${ }^{+}$preparation was preliminarily studied on 10 female Wistar Kyoto (WKY) rats (weight, 200-250 g). The rats were housed under the conditions of 12-hour light and 12-hour dark cycle and given ad libitum access to a standard laboratory diet and water. The animals received a single intradermal injection of the preparation $\left(10^{8} \mathrm{PFU} / \mathrm{ani}-\right.$ mal, $500 \mu \mathrm{l})$. The state of the animals was monitored during three weeks post-injection.

Experiments on animals were carried out in compliance with the International Guidelines of the European Convention for the Protection of Vertebrate Animals used for Experimental and Other Scientific Purposes, and the principles of Good Laboratory Practice (GLP) approved by Degree no. 267 of the Ministry of Health of the Russian Federation dated June 19, 2003.

\section{RESULTS AND DISCUSSION}

MS2 preparations containing $\mathrm{Tl}^{+}$in the amount of $2.0 \times 10^{-9}$ g-eq thallium per $10^{8} \mathrm{PFU}$ s were obtained by incubating the bacteriophage MS2 (both modified and unmodified with iRGD peptide) in the medium with $\mathrm{TlNO}_{3}$. The $\mathrm{Tl}^{+}$content per PFU was $2.0 \times 10^{-17} \mathrm{~g}$-eq ( 4 femtogram per PFU; i.e., 400 ng per $10^{8} \mathrm{PFU}$ ). No $\mathrm{Tl}^{+}$ions were detected in the buffer solution used for dialysis of $\mathrm{Th}^{+}$-filled bacteriophage, which indicates that $\mathrm{Th}^{+}$is tightly bound to phage RNA inside MS2 particles. 


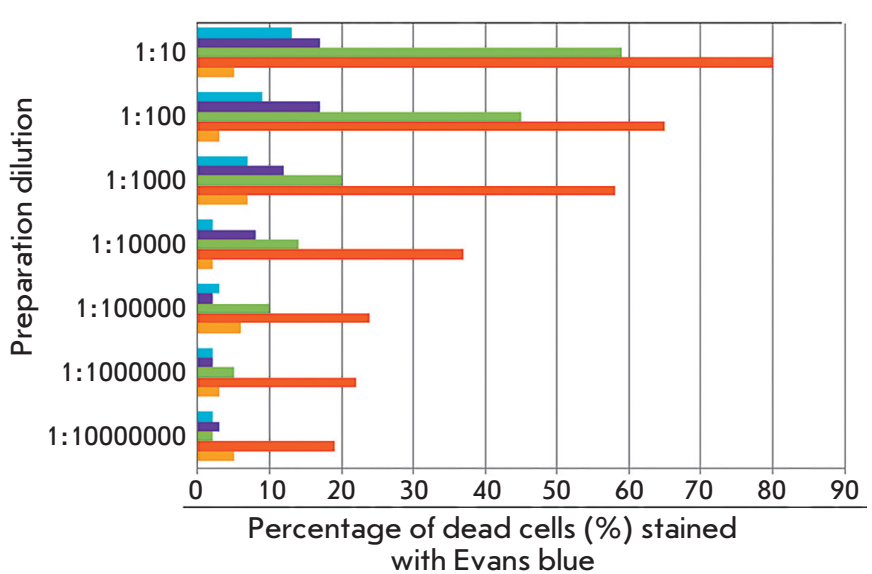

Untreated cells (control)

MCF-7 cells in the serum-free medium

MCF-7 cells in the medium supplemented with $5 \%$ fetal calf serum

MDA-MB-231 cells in the serum-free medium

MDA-MB-231 cells in the medium supplemented with $5 \%$ fetal calf serum

Fig. 1. The toxic effect of the iRGD-MS2-TI+ preparation on tumor cell cultures (cell death, \%)

Figure 1 demonstrates that the iRGD-MS2-Tl ${ }^{+}$preparation had a cytotoxic effect on hormone-dependent and hormone-independent breast cancer cells in the serum-free medium. For hormone-dependent BC (MCF-7 cells), $\mathrm{ED}_{50}$ of the iRGD-MS2-Tl $\mathrm{Tl}^{+}$preparation was slightly lower than $10^{5} \mathrm{PFU} / \mathrm{ml}$ of the culture broth, while the cytotoxic effect of the preparation was statistically significant compared to the control specimen, up to a concentration of $10 \mathrm{PFU} / \mathrm{ml}$. Hormoneindependent breast cancer (MDA-MB-231) cells were more resistant to the preparation: for these cells, $\mathrm{ED}_{50}$ in a serum-free medium was $10^{6}-10^{7} \mathrm{PFU} / \mathrm{ml}$, while the cytotoxic effect of the preparation was statistically significant compared to the control specimen, up to a concentration of $10^{4} \mathrm{PFU} / \mathrm{ml}$. The cytotoxic activity of iRGD-MS2- $\mathrm{Tl}^{+}$was much weaker in the serum-containing medium, which may be an indication that serum components and iRGD-MS2- $\mathrm{Tl}^{+}$particles compete for penetration into the cells.

In mice with $\mathrm{MCF}-7$ and MDA-MB-231 xenografts, the tumor volume was reduced 12 days following the injections of the iRGD-MS2- $\mathrm{Tl}^{+}$preparation compared to that in the control animals (Fig. 2). The necrotizing effect of iRGD-MS2- $\mathrm{Tl}^{+}$on the corresponding tumors was demonstrated histochemically. Figure 3 shows that the iRGD-MS2- $\mathrm{Tl}^{+}$preparation was more efficient in causing tumor tissue necrosis $(p<0.05)$ than
A

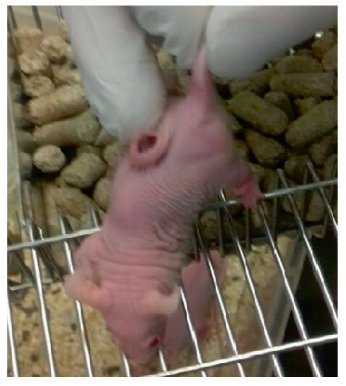

$B$

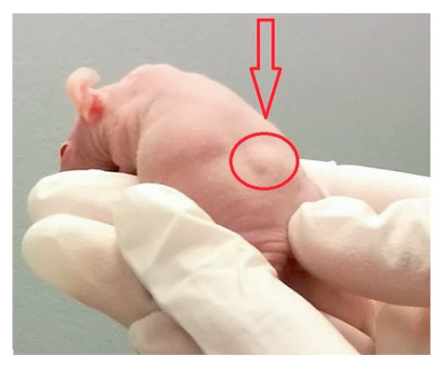

Fig. 2. MDA-MB-231 tumor in xenograft mice before (A) and after $(B)$ treatment with a iRGD-MS2-TI+ preparation

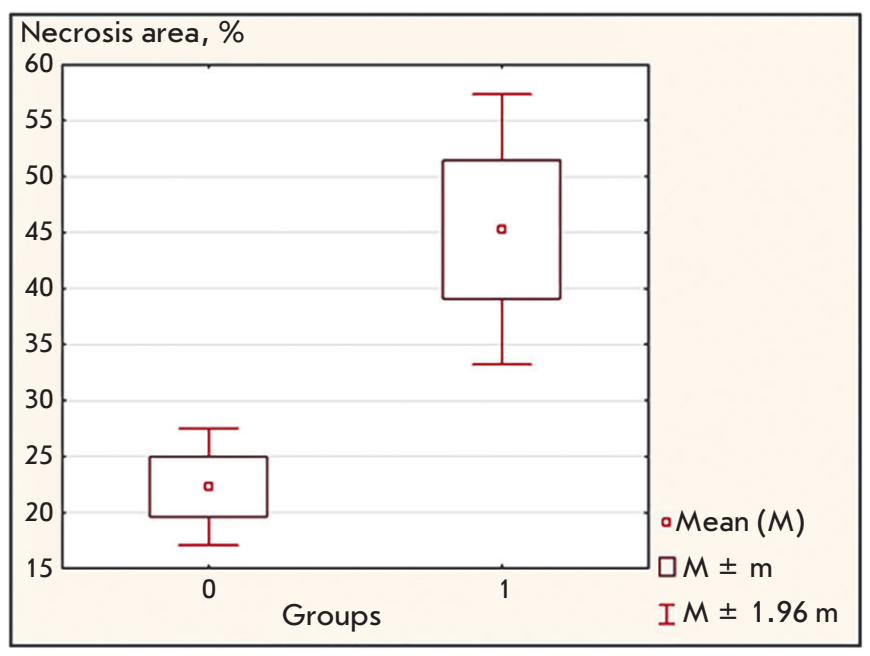

Fig. 3. Area of tumor tissue necrosis in mice xenograft of human BC. Group 1 - experimental animals that received a iRGD-MS2- $\mathrm{TI}^{+}$preparation; group 0 - control animals that received $\mathrm{R}$ GD-MS2, or $\mathrm{MS} 2-\mathrm{Tl}^{+}$, or $\mathrm{MS2}-\mathrm{Tl}^{+}$with a non-conjugated $\mathrm{R}$ GD peptide (in a solution)

peptide-conjugated phage preparations without $\mathrm{Tl}^{+}$ ions, $\mathrm{Tl}^{+}$-filled phage preparations without the peptide, or $\mathrm{Tl}^{+}$-filled phage preparations containing the nonconjugated peptide in the solution.

Evaluation of acute toxicity of the iRGD-MS2-Tl ${ }^{+}$ preparation in Wistar Kyoto (WKY) rats demonstrated that a single-dose injection of iRGD-MS2- $\mathrm{Tl}^{+}\left(10^{8}\right.$ $\mathrm{PFU} /$ animal; i.e., $1.6-2.0 \mu \mathrm{g} \mathrm{Tl} / \mathrm{kg}$ ) caused death in none of the animals after three weeks of follow-up. No noticeable changes in animal behavior were revealed. The total therapeutic dose of $\mathrm{Tl}^{+}(4 \mu \mathrm{g} / \mathrm{kg})$ was $5,000-$ fold lower than its $\mathrm{LD}_{50}(20 \mathrm{mg} / \mathrm{kg})$. 


\section{CONCLUSIONS}

Targeted delivery of ions of a toxic metal to a tumor neovasculature using phage display based on iRGD$\mathrm{MS} 2-\mathrm{Tl}^{+}$particles causes efficient degradation of the entire tumor mass, while the risk of overall toxicity is significantly reduced. Therefore, it is reasonable to recommend conducting preclinical trials of iRGD-MS2- $\mathrm{Tl}^{+}$ in order to develop a preparation which can potentially be further used to treat breast cancer. Since the iRGD peptide ligand interacts with $a_{v} b_{3}$ and $a_{v} b_{5}$ integrins on the surface of endothelial cells in the pathological vasculature [8], this drug may be efficient against other solid tumors characterized by intensive pathological neoangiogenesis.

This work was supported in part by Biotechnologiya, Ltd. The procedures for (Gly) $)_{3}-i R G D$ peptide synthesis and its conjugation to the bacteriophage MS2 were developed under the Program of Fundamental Research for State Academies of Sciences in 20132020. The peptide was synthesized using the equipment of the Core Facilities "Human Proteome" (Institute

of Biomedical Chemistry). Animal experiments were conducted at the N.N. Petrov National Medical Research Center of Oncology of the Ministry of Health of the Russian Federation. The authors are grateful to A.A. Chistov (Institute of Biomedical Chemistry, Institute of Bioorganic Chemistry) for analyzing the $i R G D$ peptide.

The materials in this article were used to obtain an $R F$ Patent 2599462 "Method for Poly-signal Activation of Apoptosis of Malignant Solid Tumor Cells" and file a U.S. patent application (application no. 15/757,285 filed March 2, 2018) and a European patent application (PCT - WO 2017052419).

\section{REFERENCES}

1. Lee M.S., Dees E.C., Wang A.Z. // Oncology (Williston Park). 2017. V. 31. № 3. P. 198-208.

2. Fan Y., Moon J.J. // Vaccines. 2015. V. 3. № 3. P. 662-685.

3. Stavrovskaya A.A., Stromskaya T.P. // Biokhimiya. 2008. V. 73. № 5. P. 735-750.

4. Korotkov S.M., Brailovskaya I.V., Kormilitsyn B.N., Furaev V.V. // J. Biochem. Mol. Toxicol. 2014. V. 28. № 4. P. 149-156.

5. Zasukhina G.D., Vasilyeva I.M., Sdirkova N.I., Krasovsky G.N., Vasyukovich L.Ya., Kenesariev U.I., Butenko P.G. // Mutat. Res. 1983. V. 124. № 2. P. 163-173.

6. Ke A., Ding F., Batchelor J.D., Doudna J.A. // Structure. 2007. V. 15. № 1. P. 281-287.

7. Leclerc H., Edberg S., Pierzo V., Delattre J.M. // J. Appl.
Microbiol. 2000. V. 88. № 1. P. 5-21.

8. Ruoslahti E. //Adv. Drug Deliv. Rev. 2017. V. 110-111. P. 3-12.

9. Knyazhev V.A., Sivov I.G., Sergienko V.I. // Moleculyarnaya genetika, mikrobiologiya i virusologiya. 2002. V. 20. № 2. P. 23-26.

10. Andreu D., Albericio F., Sole N.A., Munson M.C., Ferrer M., Barany G. // Methods Mol. Biol. 1994. V. 35. P. 91-169. 11. Synthetic peptides as antigens. / Eds van Regenmortel M.H.V., Muller S. Elsevier, 1999.

12. Donnelly D., Mihovilovic M., Gonzalez-Ros J.M., Ferragut J.A., Richman D., Martinez-Carrion M. // Proc. Natl. Acad. Sci. USA. 1984. V. 81. № 24. P. 7999-8003. 